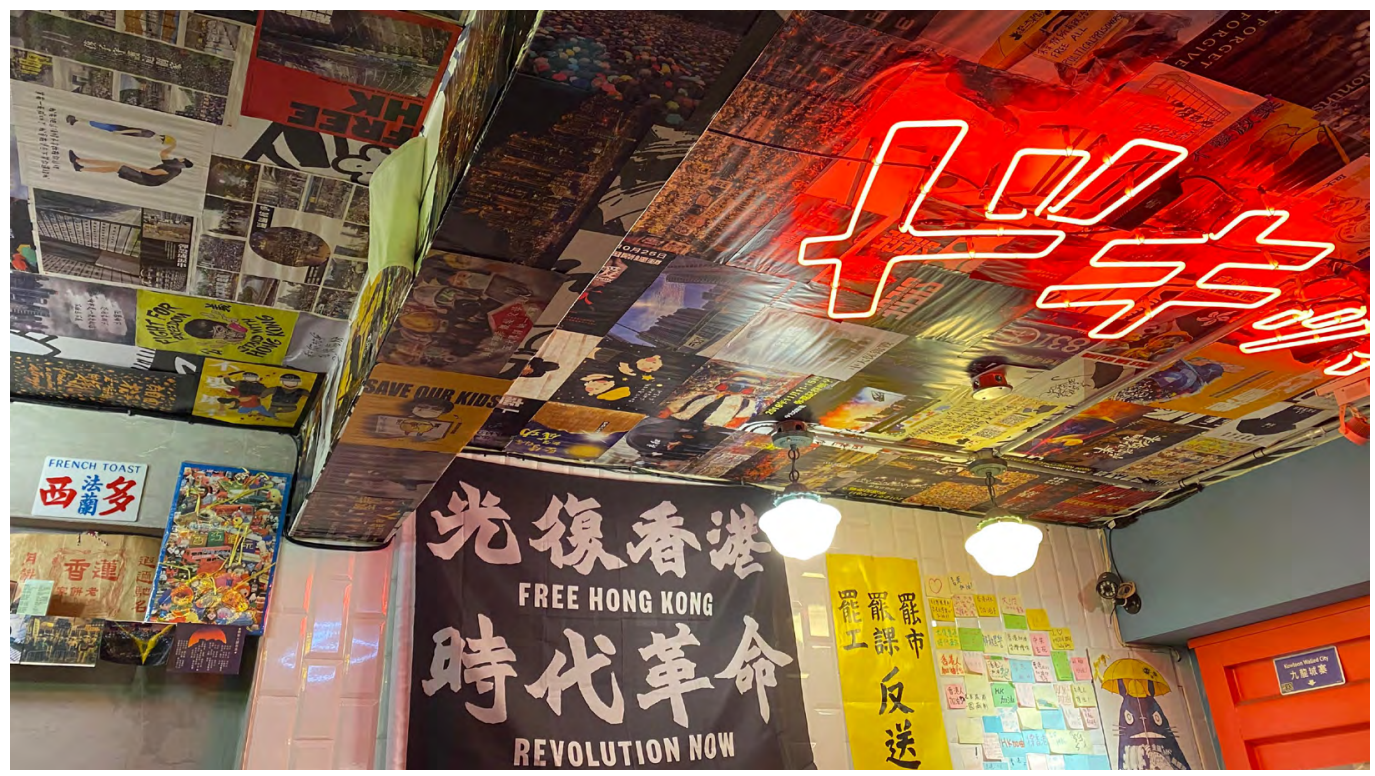

\section{Peddling the Revolution? \\ How Hong Kong's Protesters became Online Vendors in Taiwan}

\section{Ming-sho $\mathrm{HO}$ \\ Wei An CHEN}

Some former Hong Kong protesters who fled to Taiwan have resorted to selling local products online to Hong Kong-based consumers to make a living. This essay argues that these purchases become both an alternative form of financial support from Hong Kong's politically conscious consumers and business transactions endowed with political meaning. Not without ambivalences, these online vendors sell more than products, but also a lifestyle, an identity, and a commitment-in short, a revolutionary dream at a time when street protests in their home city are no longer feasible.
A Yellow Store in Taipei with protest posters, banners, and flags from wall to ceiling. PC: Wei An Chen.

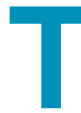
he national security legislation imposed by the People's Republic of China's rubberstamp legislature in mid-2020 has forcibly turned Hong Kong into a repressive police state. With opposition leaders and protest activists either in jail or in exile, the city's prodemocracy movement and civil society sustain relentless assaults from the authorities. Apparently, Beijing is not satisfied with merely stamping out the 2019 citywide resistance against the extradition bill, but also is bent on radically reengineering the former British colony into a submissive mainland city. As Hong Kong is undergoing a drastic transformation in the wake of a failed uprising, it is of interest to 
examine 'life after the squares' (Fernández-Savater et al. 2017). Where have the protesters gone? After the flare-up of passionate protests, how do former activists adjust to the return of 'normalcy'? And among those who have fled abroad, how do they retain allegiance to their political vision while managing to survive in an unfamiliar setting?

Hong Kong's diaspora communities have managed to maintain the momentum of the prodemocracy movement. Well-known leaders, such as former lawmakers Nathan Law and Ted Hui, have become globetrotting advocates for the Hong Kong cause. In North America, Europe, Australia, Japan, and Taiwan, immigrant associations are sprouting up to offer support for newcomers. However, beyond these salient cases, there are numerous exiled activists who are struggling to gain a footing in the host society. Although a transnational network for donations of money and protest gear (goggles, helmets, masks, and so on) emerged during the anti-extradition movement $(\mathrm{Li}$ and Fung 2021), former participants who do not have fame or connections must survive on their own wits. There are no official statistics about the number of Hong Kong protesters who have taken refuge in Taiwan, where they are able to stay on student or other visas or under a special protection program run by the government if they cross the border legally. Our understanding is that the number is no less than 1,000-an estimate that does not include those who have migrated to Taiwan not because of their involvement in the protests, but out of concern for Hong Kong's future.

Given these numbers and the lack of attention this phenomenon has received so far, how ex-protesters in Taiwan are managing to secure their livelihood on their own deserves a closer look. In particular, in this essay, we analyse the phenomenon known as 'protesters' purchasing' (手足代購) in Taiwan. Some former activists use online platforms (Instagram, Facebook, Telegram, and others) to sell Taiwanese commodities to Hong Kong-based customers. Drawing on eight in-depth interviews we conducted in 2020 and 2021 with Hongkongers and Taiwanese-including six interviews with sellers personally involved in the 'protesters' purchasing' business-complemented by data we collected by observing websites and social media accounts, we show how, while most of their patrons have access to other shopping venues for the same Taiwan-made food and goods, they are willing to pay higher than market price to support these comrades in exile. We argue that in this way such purchases become both an alternative form of financial support from Hong Kong's politically conscious consumers and business transactions endowed with political meaning. As such, these online vendors sell more than products, but also a lifestyle, an identity, and a commitment-in short, a revolutionary dream at a time when street protests in their home city are no longer feasible.

Broadly speaking, 'protesters' purchasing' is part of the so-called Yellow Economic Circle (黄色經 濟圈) that has emerged since the autumn of 2019. At its core, it amounts to a consumer campaign to patronise pro-movement stores or 'yellow stores' (黄店) and to boycott pro-government stores or 'blue stores' (藍店) (Chan and Pun 2020). Beyond the immediate goal of political consumerism, the campaign also envisions a utopia of economic solidarity, in which like-minded Hongkongers form a mutually supportive and redistributive community. Despite a similar political intent, Taiwan's 'protesters' purchasing' deviates in a few significant ways. First, internet-based transactions are more anonymous than those in physical shops. Second, as there is no need to rent shop space and the seller purchases products only after an order has been paid, it is a business that requires no advanced capital and thus is easily accessible to young and poor people. Last, it involves an almost exclusively one-way flow of Taiwan-made commodities to Hong Kong and a flow of cash in the opposite direction. There is no circularity envisioned in the Hong Kong-based Yellow Economic Circle.

\section{Origins}

Hongkongers are avid online shoppers, eagerly embracing the convenience of e-commerce. During the 2019 protests, many participants and supporters purchased protective gear such as helmets and masks from Taobao, a China-based 
online marketplace, before such items were removed from the catalogue. Hongkongers are also frequent international travellers who enjoy buying foreign goods, including Korean cosmetics, Japanese snacks, and Thai groceries. Taiwanese snacks, fruit, and creative cultural products are also increasingly popular in the city, partly for political reasons. Since the 2014 Umbrella Movement, Taiwan's government and civil society organisations have stood behind Hongkongers' struggle for democracy, incurring criticism from the Chinese authorities. As such, consuming Taiwanese products carries a symbolic meaning of political insubordination. Moreover, the Covid-19 pandemic has played a facilitating role. As Taiwan imposed a travel ban on non-essential international visitors from February 2020, Hongkongers' online demand for Taiwanese products soared as they were no longer able to travel and purchase them on their own.

The first wave of Hong Kong protesters fled to Taiwan immediately after the occupation of the Legislative Council on 1 July 2019. As the confrontation escalated during the summer, the numbers gradually increased, climaxing in the wake of the two university sieges in November. After the Covid-related restrictions were implemented, the flow was reduced to a trickle. Before the pandemic, the Hong Kong-Taiwan Taoyuan aviation route was among the busiest for international flights, thus those protesters who were most at risk of being arrested could rush to the airport and easily get a seat to Taiwan. In less than two hours, they would descend on an island of freedom-one of the reasons Taiwan was often chosen as the first overseas layover before proceeding to other countries.

Of those who have chosen to stay in Taiwan, some have been able to receive financial support from Hong Kong donors or are eligible for humanitarian assistance from the Taiwanese Government. Yet, to work legally, they need a government-issued alien residence certificate and work permit, and these official documents take time to be processed. As such, online vending has become one of the most accessible ways to make a living for these stranded sojourners. With merchandise easily available from convenience stores or megastore outlets, all that is needed is a social media page to display one's catalogue. Once a purchase order arrives, vendors simply buy the commodities and take them to drop-off points for delivery. As the purchase cost and shipment fee are reflected in the sale price, profit basically comes from the willingness to run errands for customers. Given the small scale of such transactions, these online vendors cannot compete with large retailers in terms of price and delivery time. They can stay in business only as long as Hong Kong-based consumers are willing to patronise them to express their support.

Probably the best-known start-up in this field is RS International, which has just over 6,000 followers on Instagram. It is far from the biggest online vendor specialising in Taiwanese products; other, apolitical sellers have more than 13,000 followers. Its operator claims to hail from the Dragon Slaying Brigade (屠龍小隊), a militant group with dozens of members who engaged in violent attacks against the police in Hong Kong. Such clandestine groups were not uncommon at the height of the protests, but the Dragon Slaying Brigade was one of the most famous because its participants granted media interviews to publicise their beliefs. Different stories have circulated regarding their whereabouts after their decision to disband. Some say the members were never identified and were able to return to normal life unscathed; others believe that most members were arrested and only a few managed to escape abroad. What we know for sure is that a person who claimed to belong to the now defunct brigade arrived in Taiwan and launched RS International, purchasing for Hong Kong clients, in 2020. Unsurprisingly, the legendary audacity and mysterious aura of the group brought attention to the business operation.

According to the explanation provided on RS International's website, the initials 'RS' refer to 'Radical Solider' and 'Rebuild System', indicating their radical motivations. Their self-description reads as follows:

\footnotetext{
We are a group of 'stupidly naïve' [懵撚] people who were born into a chaotic time [亂世]. After several rounds of upheavals, we are forced to tread on the path of international study [遊學] and give up what many
} 
of you have taken for granted and can easily access. We have to readjust our mindset and get started on an unknown path.

This passage is so densely coded that its subtle meanings are easy to overlook. For instance, 'international study' is a euphemism for those young protesters who were forced to flee abroad. And the self-mocking reference to their own 'stupid naivety' is an implicit acknowledgement of their involvement in the violent protests. Such coded expressions are not likely to go unnoticed by Hong Kong's politically conscious internet users. Yet, despite the seller's self-proclaimed radicalism, the commodities displayed on RS International's digital shelves include food, snacks, cosmetics, and skincare products readily available in Taiwan, and even some made in South Korea. Except for T-shirts bearing the seller's name, there are no politically themed products for sale.

Unable to exploit the reputation of the Dragon Slaying Brigade, other online vendors struggle to convey their political orientations to attract potential customers. Some choose to share news reports about Hong Kong and Taiwanese politics on their platforms with their own comments so viewers know clearly what they stand for. Others include the terms 'protesters' (手足) or 'yellow stores' in their account name and description, or attach a barrage of hashtags with familiar protest slogans such as 'Revolution of Our Time' (時代 革命) and 'Reclaim Hong Kong' (光復香港) to promote their merchandise. They fear that if they do not emphasise their political beliefs enough, potential customers will think their stores are not 'yellow' enough.

\section{Marketing Strategies}

Online vending is probably the easiest form of entrepreneurship in the digital age, but its low threshold requirements easily attract many participants, who then have to face constant pressure to survive due to competition and low profit margins. Many of our interviewees said they got their start thanks to friends in Hong Kong. As one of them said: 'I tell my Hong Kong friends that I am running this website and ask them whether their friends might need something. Some of these friends are people they met or got to know during the street protests. In addition, some have been able to use certain social media channels to attract customers. There have been several sales events to promote the Yellow Economic Circle in Hong Kong, both digital and physical, and these occasions also help the online start-ups to gain attention.

Nevertheless, online vending remains a crowded field with too many competitors. One online vendor expressed her frustration in these terms:

Many yellow stores in Hong Kong are now
selling Taiwanese products. Yellow stores
should be helpful toward protesters; now with
so many protesters in Taiwan in the business
of purchasing to support themselves, why do
they choose to compete with us ... Hong Kong
is a free port, and these yellow stores can sell
Korean and Indonesian products as well. The
world is so big, and they should not scramble
for Taiwanese products.

Clearly, the more Hong Kong-based stores that sell Taiwanese products, the narrower the profit space for Taiwan-based online vendors becomes. Since Taiwanese products have come to represent political defiance, they are a hot commodity for politically frustrated consumers in Hong Kong. Another interviewee revealed that she and her business associates were bitterly envious of the fact that Lam Wing-Kee, a publisher who was detained in China for more than six months in 2015 for a scandalous book about Xi Jinping's private life, was able to crowd-fund TWD $\$ 5$ million to launch his Causeway Bay Bookstore (銅鑼灣書 店) in downtown Taipei. Thanks to his halo as a freedom fighter, Lam was able to corner the attention and the money of supporters.

Facing such tough competition, sellers resort to various marketing strategies to keep their business afloat. First, online vendors can add personal touches to the commodities they sell. For instance, they generously share their experiences with a particular skincare product and the results of their personal experiments. In this way, they pose as 
friends spontaneously sharing new information, rather than traders promoting a cold business transaction.

Second, while many products displayed in the online catalogues are readily available at retail points and vendors earn only the price markup, it makes business sense to pursue a cost-reduction strategy such as accessing upstream producers directly to avoid middlemen. Thus, one vendor specialising in Taiwanese fruit took a road-trip to visit farm after farm in search of pineapple growers to be his suppliers.

Third, while vendors do not shy away from selling mainstream and well-known products, such as pineapple cakes, they are troubled by the low profit margin on such merchandise. For this reason, they typically concentrate on developing a few niche products with which Hong Kongbased customers are unfamiliar. For instance, a handmade cookie brand whose store was once visited and recommended by Taiwanese President Tsai Ing-wen became instantly popular with customers. Alternatively, some vendors collaborate with Taiwanese manufacturers to develop new products or seek exclusive sales rights. One of our interviewees revealed that niche products like these made up his largest source of profit.

Last, beyond the catalogued merchandise, vendors are also willing to provide personalised service to frequent customers with special needs. One interviewee said he once scouted Taipei's second-hand bookstores for a particular collection of comic books that was not available in Hong Kong. His legwork was compensated by the processing fee, which was $20-25$ per cent of the procurement cost.

With such a range of marketing strategies, our interviewees enjoyed various degrees of business fortune. A particularly successful vendor was able to expand by opening a storefront in Hong Kong so he could access more customers. On the other hand, another interviewee chose to drop out of the business shortly after our interview. Although we did not have the chance to conduct a follow-up interview to ask why, it is likely the cutthroat competition and low profit margins were the main reasons. For many of our interviewees, 'protesters' purchasing' was not their main source of income, but a side job at most, and they did not intend to stay in this line of business indefinitely. Nevertheless, since many buyers are typically motivated by the intention to help exiled former protesters, it is necessary for vendors to spend time maintaining personal relationships with their patrons. Socialising with customers via digital platforms therefore emerges as a core task in the business. One interviewee revealed:

For my business, I use a lot of time in
managing my Instagram page. I spend more
than 12 hours a day on my mobile phone. I
have many frequent customers on Instagram,
so I need to chat with them to maintain our
relationship. We talk about many things in
our daily life.

Another shared a similar experience:

I frequently contact my customers, and I even chat with them like friends. I share my life in Taiwan and exchange our mutual cares. Recently, there was an earthquake in Taiwan and the weather is getting cold, and these are the topics that they are interested in. I am away from Hong Kong and I still want to know everything happening there. They can update me with the newest development.

In short, despite the business innovations mentioned above, 'protesters' purchasing' remains akin to direct selling in its heavy reliance on personal relationships (Biggart 1989).

\section{Profit and Politics}

Our analysis is not meant to imply that these online vendors are merely driven by profit. In addition to securing their livelihood, these people remain committed to the vision of the prodemocracy movement. Moreover, they are conscious of the fact that several self-styled yellow stores in Hong Kong are morally dubious because they offer overpriced and substandard goods and services. This explains why most of our interviewees revealed a certain uneas- 
iness with the Yellow Economic Circle slogan and insisted on emphasising the quality of their goods and services. They take pride in the fact they are working to fulfill their personal material needs and live up to their commitment to the movement at the same time. These micro-entrepreneurs support themselves by honest work and, in promoting Taiwanese products, they are envisioning an economic future for Hong Kong that is less reliant on mainland China. Thus, one interviewee insisted on not using Chinese-operated delivery services because 'we start the business in the hope that Hongkongers do not buy China-made stuff. We do not want China to earn a penny from us.' Another made it a principle to thoroughly investigate the sources of her commodities to make sure the materials were not from China. As such, these online vendors see their economic operations as being closely aligned with their political goals.

Mixing profit and politics inevitably creates some moral grey zones. For instance, when chatting with their online customers, do these online vendors intend to make sincere friendships or do they only have their business interests in mind? Are Hong Kong-based customers altruistic sponsors of the exiles for a noble cause, or are they shrewd consumers who aim at maximising their economic benefits? If our interviewees were forced to answer, it would probably be: 'Both.' And here lies the crux of the enigma of 'protesters' purchasing', because it amounts to an experimental and creative mixture of movement activism and business transactions, and this delicate balance is likely to be disrupted by a shift to one extreme at the expense of the other.

We do not intend our preliminary observations to provide a final judgement on this new phenomenon, as it is still evolving. We acknowledge that there are plenty of moral ambiguities in 'protesters' purchasing' other than this tension between profits and politics. For instance, former protesters typically belong to a victimised generation of young Hongkongers who came of age in an increasingly unequal capitalist society. Yet, they are perfectly willing to act as the diligent foot-soldiers of an expanding platform economy that heavily relies on a disposable precariat. However, from another perspective, they succeed in inserting a political dimension into the otherwise excessively commer- cialised world of social media. Their insistence on Taiwan-made products and their marketing of Taiwan's democratic values help to 're-enchant a disenchanted world', to borrow a phrase from Ritzer (2010). In other words, while the relentless logic of profit-making might be the same, Hong Kong's former protesters have succeeded in adding a political charm to Taiwanese commodities, making them appear immensely superior to China-made ones.

However, is Taiwan's capitalism any better than mainland China's? Sweatshops will probably continue to exist in many places regardless of the local political system, but there is a difference in that, while democratic governments tolerate trade unions and resistance movements, dictators feel no qualms about quashing them. The real question is whether democracy can be promoted by such market-conforming strategies. The fact that 'protesters' purchasing' originates from a port city that takes pride in unbridled wealth accumulation and thrives in an era of increasingly frictionless global flows of money and commodities gives us pause. Only time will tell what direction such a politicised capitalism will take.

ADDENDUM (6 May 2022): The authors would like to acknowledge other scholarship in feminist, Holocaust, and peace studies in which the concept of 'hierarchy of victimhood' was first developed, especially the following:

Butler, Judith. 2010. Frames of War: When Is Life Grievable?

London and New York, NY: Verso Books.

Charmaz, Kathy. 1999. 'Stories of Suffering: Subjective Tales and Research Narratives.' Qualitative Health Research 9(3): 362-82.

Dawidowicz, Lucy S. 1981. The Holocaust and the Historians. Cambridge, MA: Harvard University Press.

Stone, Louise. 2018. 'Disease Prestige and the Hierarchy of Suffering: Suffering Should Not Be Hierarchical, and Care Should Not Be Predicated on the Prestige That a Disease Attracts.' Medical Journal of Australia 208(2): 60-62.

For an example of the application of this concept to the Hong Kong context, see:

Sham, Priscilla. 2020. 'Who Deserves Compassion? A Hierarchy of Suffering in Hong Kong's Anti-Extradition Movement.' Medium, 23 February. medium.com/@priscillasham/ who-deserves-compassion-a-hierarchy-of-suffering-in-hongkongs-anti-extradition-movement-a12592950c4b. 
This text is taken from Made in China Journal: Volume 6, Issue 3, 2021, edited by Ivan Franceschini, Nicholas Loubere and Shui-yin Sharon Yam, published 2022 by ANU Press, The Australian National University, Canberra, Australia.

doi.org/10.22459/MIC.06.03.2021.11 